Article - Agriculture, Agribusiness and Biotechnology

\title{
Lipase Production by Aspergillus niger C by Submerged Fermentation
}

Laisy Garcia Ribeiro Lima ${ }^{1}$

https://orcid.org/0000-0001-7006-3961

Márcia Monteiro Machado Gonçalves ${ }^{1}$

https://orcid.org/0000-0001-8935-7580

Sonia Couri ${ }^{1}$

https://orcid.org/0000-0002-2691-8317

Verônica Ferreira Melo ${ }^{2}$

https://orcid.org/0000-0003-4010-5889

Gizele Cardoso Fontes Sant'Ana ${ }^{1^{*}}$

https://orcid.org/0000-0001-5204-1179

Antônio Carlos Augusto da Costa ${ }^{1}$

https://orcid.org/0000-0003-2891-4384

${ }^{1}$ Rio de Janeiro State University, Chemical Institute, Rio de Janeiro, RJ, Brazil; ${ }^{2}$ Federal Institute of Rio de Janeiro, Department of Food, Rio de Janeiro, RJ, Brazil.

Received: 2018.03.01; Accepted: 2019.07.09.

*Correspondence: gizele.santana@uerj.br; Tel.: +55-21- 23340138 (G.C.F.S)

\section{HIGHLIGHTS}

- Lipase was production by $A$. niger using sucrose and soybean oil as carbon source.

- Experiment design was an efficient tool in improving $A$. niger lipase production.

- Lipase production kinetics indicated good yield levels in a short fermentation time.

Abstract: This study aimed to evaluate the effects of variables on the process of lipases production by Aspergillus niger $\mathrm{C}$ by submerged fermentation ( $\mathrm{SmF})$. The production assays were performed in shake flasks for 72 hours at $150 \mathrm{rpm}$ and $32^{\circ} \mathrm{C}$. First, a fractional factorial design $2^{5-1}$ (FFD) was carried out to evaluate the effect of the following process variables: sucrose, ammonium sulphate, soybean oil, yeast extract concentration and $\mathrm{pH}$. After the selection of the variables that significantly influenced the lipase production, a central composite rotational design $2^{2}$ (CCRD) was used, aiming to find the most favorable operational conditions. The selected assay condition $\left(15.0 \mathrm{~g} \cdot \mathrm{L}^{-1}\right.$ sucrose, $4.0 \mathrm{~g} . \mathrm{L}^{-1}$ 
ammonium sulphate, $4.0 \mathrm{~g} \cdot \mathrm{L}^{-1}$ soybean oil and $1.0 \mathrm{~g} \cdot \mathrm{L}^{-1}$ yeast extract at $\mathrm{pH} 5.0$ ) was the one that presented a lipase activity of $27.46 \mathrm{U} \cdot \mathrm{mL}^{-1}$. It was very close to that best assay $(30.76$ U. $\mathrm{mL}^{-1}$ ), but using half of the inducer concentration, consequently reducing process cost. The kinetics of lipase production showed that the highest specific activity was 57.17 U.mg-1. The $\mathrm{pH}$ and temperature effects on lipase activity produced in this study was investigated. The optimum activity was found in a more acidic $\mathrm{pH}(5.0-6.0)$ and $55^{\circ} \mathrm{C}$.

Keywords: Lipases; Submerged fermentation; Aspergillus nige; Experimental design.

\section{INTRODUCTION}

Enzymes are considered as nature's catalysts and the particular benefits offered by them are specificity, mild conditions of use and reduced waste generation. In comparison to a chemical process, enzymatic processes present less energy requirements and higher quality of the obtained product. The interest in the production of lipases is associated with its biotechnological potential due to their catalytic action in hydrolytic reactions, esterification, transesterification and interesterification [1].

Lipases (glycerol ester hydrolases EC 3.1.1.3) catalyze the hydrolysis of triglycerides to free fatty acids and glycerol. These enzymes can also catalyze esterification, interesterification, acidolysis, alcoholysis and aminolysis in addition to the hydrolytic activity on triglycerides [2]. Lipases constitute the three major known digestive enzymes and are the most important group of biocatalysts for biotechnological applications. The number of available industrial lipases has increased considerably since the 1980 s in response to an increasing demand for these biocatalysts [3]. Considering that lipases accounting for approximately $10 \%$ of the global industrial enzyme [4], this market is estimated to reach $\$ 0.63$ billion in 2021 at a compound annual growth rate (CAGR) of 4.7\% for 2016-2021 [5].

Lipases can be of animal, plant and microbial sources. The microbial enzymes present wide industrial applications due to their stability, selectivity and specificity. Many industrial lipases have been produced, purified and cloned from bacteria and fungi that include Aspergillus species. They are widely used in industrial applications, such as in dairy and food manufacture, leather and detergent industry. Recently, they faced novel biotechnological applications such as production of cosmetics, enantiopure pharmaceuticals, agro-chemicals, flavor compounds and synthesis of biopolymers and biodiesel [6]. Despite the presence of a large number of already discovered and characterized lipolytic enzymes, the search for new biological routes of lipolytic enzymes displaying unique and specifically desired properties, such as stereo-, regio- and enantio-selective transformation [7] and the knowledge of production parameters remains important.

Lipase production is affected by the medium $\mathrm{pH}$, temperature, medium composition, inoculation volume, aeration, agitation and many other factors. These factors have been studied in a number of microorganisms and several strategies have been used to model and to optimize the parameters of the fermentation process using statistical experimental designs [8].

Lipase production by $A$. niger in fermentation processes is commonly characterized by a mixed carbon source, usually a sugar and a lipid (edible oils, fatty acids, and so on) to grow the microorganism and to induce the production of the enzyme. Previous studies, using sucrose, glucose and olive oil, have shown that glucose has a negative effect on lipase production by $A$. niger. However, sucrose contributes greatly to lipase production and showed positive effect [9]. In general, vegetable oils are used as inducers of lipase synthesis, in addition to being carbon source. According to Messias et al [10], the soybean oil was effective as inducer for the production of fungal lipases.

The common nitrogen sources used for microbial growth are corn steep liquor, soy flour, yeast extract, peptone, urea, nitrate, and ammonium salts. Different effects in lipase production have been reported depending on the nitrogen source and the microorganism [3]. Ammonium salts supported the best growth as well as lipase production by Aspergillus niger [11]. 
Extracellular lipases for industrial applications can be produced by submerged and solid state fermentations [12]. Solid-state fermentation (SSF) involves the cultivation of microorganisms on a solid substrate, such as grains, rice and wheat bran, in absence or near absence of free water. Submerged fermentation (SmF) has been defined as fermentation in liquid medium, which contain soluble nutrients, or as fermentation in the presence of excess water [13]. SmF offer many advantages over SSF, such as, better monitoring operational parameters, homogeneous medium, which allows a more effective heat and mass transfer, microorganism inoculum remains completely submerged and distributed evenly favoring the nutrient absorption [14].

Most reports in the literature use SSF and different strains of $A$. niger for the lipase production [15-17]. Regarding the advantages of SmF, this process was selected for lipase production from the strain $A$. niger $\mathrm{C}$, using statistical design for evaluation of the effects of some variables of process.

\section{MATERIAL AND METHODS}

\section{Microorganism}

The wild strain of $A$. niger $\mathrm{C}$ used in this study was provided by the culture collection of Embrapa Food Agroindustry, Rio de Janeiro-Brazil. The culture was kept on dry sand at $-20{ }^{\circ} \mathrm{C}$ and activated by transferring spores twice to basic salt medium agar slants $\left(3.0 \mathrm{~g} . \mathrm{L}^{-1}\right.$ $\mathrm{NaNO}_{3}, 1.0 \mathrm{~g} \cdot \mathrm{L}^{-1} \mathrm{~K}_{2} \mathrm{HPO}_{4}, 0.5 \mathrm{~g} \cdot \mathrm{L}^{-1} \mathrm{MgSO}_{4} \cdot 7 \mathrm{H}_{2} \mathrm{O}, 0.5 \mathrm{~g} \cdot \mathrm{L}^{-1} \mathrm{KCl}, 0.01 \mathrm{~g} \cdot \mathrm{L}^{-1} \mathrm{FeSO}_{4} \cdot 7 \mathrm{H}_{2} \mathrm{O}$, $30.0 \mathrm{~g} . \mathrm{L}^{-1}$ agar at $\left.\mathrm{pH} 5.5\right)$ with $2.0 \%(\mathrm{v} / \mathrm{v})$ of soybean oil as carbon source. The slants were incubated for 7 days at $30^{\circ} \mathrm{C}$. After, the slants of $A$. niger $\mathrm{C}$ were kept at $4^{\circ} \mathrm{C}$ [18].

\section{Inoculum preparation}

Spores from agar slant cultures were used to inoculate corncob medium for fungi propagation. The spores were suspended with $10 \mathrm{~mL}$ of $0.3 \%$ Tween 80 , and approximately $1 \mathrm{~mL}$ of suspension was dripped on ground corncob medium. Inoculation was carried out in $125 \mathrm{~mL}$ shake flasks containing $4.6 \mathrm{~g}$ ground corn cob and $6 \mathrm{~mL}$ solution containing: $56 \mathrm{~g} \cdot \mathrm{L}^{-1}$ peptone, $0.76 \mathrm{~g}^{-\mathrm{L}^{-1}} \mathrm{~K}_{2} \mathrm{HPO}_{4}, 36 \mathrm{~g} . \mathrm{L}^{-1} \mathrm{ZnSO}_{4}, 46 \mathrm{~g} . \mathrm{L}^{-1} \mathrm{Na}_{2} \mathrm{SO}_{4}, 0.01 \mathrm{~g} . \mathrm{L}^{-1} \mathrm{MnSO}_{4}$, and $0.5 \%$ $\mathrm{H}_{2} \mathrm{SO}_{4}$. After incubation at $30^{\circ} \mathrm{C}$ for five days, $20 \mathrm{ml}$ of $0.3 \%$ Tween 80 were added to the medium and the flask was stirred vigorously. Spores were separated by filtration through gauze [18]. A spore suspension $\left(10^{6}\right.$ spores. $\left.\mathrm{mL}^{-1}\right)$ was used as a inoculum. The number of spores. $\mathrm{mL}^{-1}$ in the suspension was count by using a Neubauer chamber.

\section{Experimental designs}

Two experimental designs were carried out in order to improve lipase production process by $A$. niger C. First, a fractional factorial design (FFD) $2^{5-1}$ was carried out to verify the effects of $\mathrm{pH}$, sucrose, soybean oil as inductor, yeast extract and ammonium sulphate concentration on lipase production. After that, a central composite rotatable design (CCRD) $2^{2}$ was used to investigate the effects of $\mathrm{pH}$ and soybean oil. In these designs, a set of 19 and 11 experiments, respectively, including three replicates at the central point, were performed. The range and the levels of the variables herein investigated are given in Tables 1 and 2. 
Table 1. Experimental range and levels of the independent variables used in the FFD $2^{5-1}$

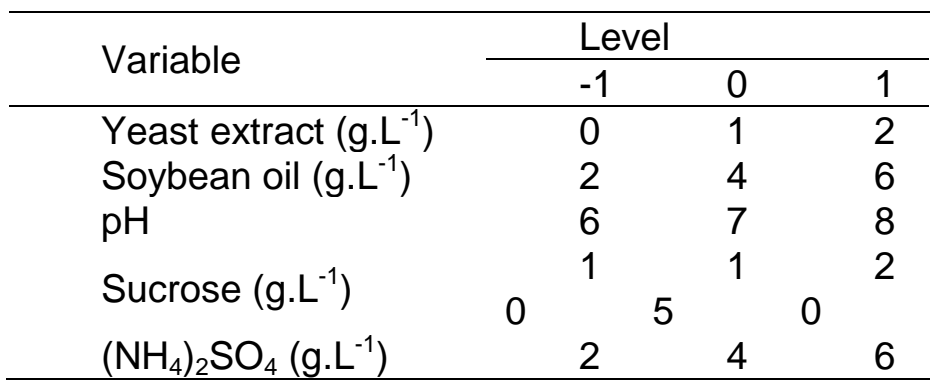

For a second experimental design the sucrose, ammonium sulphate and yeast extract concentrations were fixed at 15,4 and $1 \mathrm{~g} . \mathrm{L}^{-1}$, respectively. Lipase activity was taken as dependent variable of the experimental design. "Statistica" (version 7.0) software was used for regression and graphical analyses of the data obtained.

Table 2. Experimental range and levels of the independent variables used in the CCRD $2^{2}$

\begin{tabular}{llllll}
\hline \multirow{2}{*}{ Variable } & \multicolumn{5}{c}{ Level } \\
\cline { 2 - 6 } & -1.41 & -1 & 0 & 1 & 1.41 \\
\hline Soybean oil $\left(\mathrm{g} \cdot \mathrm{L}^{-1}\right)$ & 3.18 & 4 & 6 & 8 & 8.82 \\
$\mathrm{pH}$ & 4.59 & 5 & 6 & 7 & 7.41 \\
\hline
\end{tabular}

\section{Lipase production}

The medium used for lipase production optimization in the first design experiments was: sucrose $\left(10,15\right.$ and $\left.20 \mathrm{~g} \cdot \mathrm{L}^{-1}\right)$, soybean oil $\left(2,4\right.$ and $\left.6 \mathrm{~g} \cdot \mathrm{L}^{-1}\right)$, yeast extract $\left(0,1\right.$ and $\left.2 \mathrm{~g} \cdot \mathrm{L}^{-1}\right)$, $\left(\mathrm{NH}_{4}\right)_{2} \mathrm{SO}_{4}\left(2,4\right.$ and $\left.6 \mathrm{~g} \cdot \mathrm{L}^{-1}\right), \mathrm{KH}_{2} \mathrm{PO}_{4}\left(2 \mathrm{~g} . \mathrm{L}^{-1}\right), \mathrm{MgSO}_{4} \cdot 7 \mathrm{H}_{2} \mathrm{O}\left(0.5 \mathrm{~g} \cdot \mathrm{L}^{-1}\right), \mathrm{KCl}\left(0.5 \mathrm{~g} . \mathrm{L}^{-1}\right)$, $\mathrm{ZnSO}_{4}\left(5 \mathrm{mg} \cdot \mathrm{L}^{-1}\right), \mathrm{FeSO}_{4} \cdot 7 \mathrm{H}_{2} \mathrm{O}\left(23 \mathrm{mg} \cdot \mathrm{L}^{-1}\right), \mathrm{CuSO}_{4} \cdot 5 \mathrm{H}_{2} \mathrm{O}\left(6 \mathrm{mg} \cdot \mathrm{L}^{-1}\right), \mathrm{MgSO}_{4} \cdot 5 \mathrm{H}_{2} \mathrm{O}(20$ $\left.\mu \mathrm{g} \cdot \mathrm{L}^{-1}\right)$, and $\mathrm{pH}(6,7$ and 8$)$. For the second design experiments the medium used is: sucrose $\left(15 \mathrm{~g} \cdot \mathrm{L}^{-1}\right)$, soybean oil $\left(3.18,4,6,8\right.$ and $\left.8.82 \mathrm{~g} \cdot \mathrm{L}^{-1}\right)$, yeast extract $\left(1 \mathrm{~g} \cdot \mathrm{L}^{-1}\right)$, $\left(\mathrm{NH}_{4}\right)_{2} \mathrm{SO}_{4}\left(4 \mathrm{~g} \cdot \mathrm{L}^{-1}\right), \mathrm{KH}_{2} \mathrm{PO}_{4}\left(2 \mathrm{~g}^{-1} \mathrm{~L}^{-1}\right), \mathrm{MgSO}_{4} .7 \mathrm{H}_{2} \mathrm{O}\left(0.5 \mathrm{~g} \cdot \mathrm{L}^{-1}\right), \mathrm{KCl}\left(0.5 \mathrm{~g} \cdot \mathrm{L}^{-1}\right), \mathrm{ZnSO}_{4}(5$ $\left.\mathrm{mg} \cdot \mathrm{L}^{-1}\right), \mathrm{FeSO}_{4} \cdot 7 \mathrm{H}_{2} \mathrm{O}\left(23 \mathrm{mg} \cdot \mathrm{L}^{-1}\right), \mathrm{CuSO}_{4} \cdot 5 \mathrm{H}_{2} \mathrm{O}\left(6 \mathrm{mg} \cdot \mathrm{L}^{-1}\right), \mathrm{MgSO}_{4} \cdot 5 \mathrm{H}_{2} \mathrm{O}\left(20 \mu \mathrm{g} \cdot \mathrm{L}^{-1}\right), \mathrm{pH}$ $(4.59,5,6,7$ and 7.41$)$.

$50 \mathrm{~mL}$ of production medium was prepared and distributed in Erlenmeyer flasks of 250 $\mathrm{mL}$ capacity. Culture medium to flask ratio used was $1: 5$ to provide better aeration. After sterilization of the fermentation medium at $111^{\circ} \mathrm{C}$ and $0.5 \mathrm{~atm}$ for 20 minutes, the spore suspension was inoculated into each flask with a final concentration of $10^{6}$ spores. $\mathrm{mL}^{-1}$. Then, the inoculated medium was incubated in a shaker incubator at $150 \mathrm{rpm}$ for $72 \mathrm{~h}$ at $32^{\circ} \mathrm{C}$ [11]. At the end of fermentation, mycelium was filtered by Whatman's filter paper.

\section{Kinetics of lipase production}

To evaluate the kinetics of lipase production by $A$. niger $C$, in the condition selected in CCRD $2^{2}$, samples were taken every 12 hours for analysis of the dry biomass, total reducing sugars, protein and specific activity.

The medium for lipase production was: sucrose $\left(15.0 \mathrm{~g} \cdot \mathrm{L}^{-1}\right)$, soybean oil $\left(4.0 \mathrm{~g} \cdot \mathrm{L}^{-1}\right)$, yeast extract $\left(1.0 \mathrm{~g} \cdot \mathrm{L}^{-1}\right),\left(\mathrm{NH}_{4}\right)_{2} \mathrm{SO}_{4}\left(4.0 \mathrm{~g} \cdot \mathrm{L}^{-1}\right), \mathrm{KH}_{2} \mathrm{PO}_{4}\left(2 \mathrm{~g} \cdot \mathrm{L}^{-1}\right), \mathrm{MgSO}_{4} .7 \mathrm{H}_{2} \mathrm{O}\left(0.5 \mathrm{~g} . \mathrm{L}^{-1}\right), \mathrm{KCl}$ $\left(0.5 \mathrm{~g} \cdot \mathrm{L}^{-1}\right), \quad \mathrm{ZnSO}_{4}\left(5 \mathrm{mg} \cdot \mathrm{L}^{-1}\right), \mathrm{FeSO}_{4} \cdot 7 \mathrm{H}_{2} \mathrm{O}\left(23 \mathrm{mg}^{-1} \mathrm{~L}^{-1}\right), \mathrm{CuSO}_{4} \cdot 5 \mathrm{H}_{2} \mathrm{O}\left(6 \mathrm{mg} \cdot \mathrm{L}^{-1}\right)$, $\mathrm{MgSO}_{4} \cdot 5 \mathrm{H}_{2} \mathrm{O}\left(20 \mu \mathrm{g} \cdot \mathrm{L}^{-1}\right), \mathrm{pH} 5.0$.

\section{Analytical determinations}

\section{Lipase Activity}

Determination of lipase activity in the crude enzyme extract was done using the titrimetric method [19]. This method is based on the quantification of fatty acids released 
after the reaction between olive oil emulsion and enzyme extract. Reaction mixture containing $5 \mathrm{~mL}$ of the emulsion $(1.4 \mathrm{~mL}$ of water, $1.4 \mathrm{~mL}$ of olive oil and $0.34 \mathrm{~g}$ of gum Arabic prepared by mixing for $1 \mathrm{~min}$ at room temperature), $4 \mathrm{~mL}$ of $50 \mathrm{mM}$ sodium phosphate buffer ( $\mathrm{pH} \mathrm{5.0)}$ and $1 \mathrm{~mL}$ enzyme extract was incubated for $15 \mathrm{~min}$ at 35ㅇ. Reaction was stopped by adding $10 \mathrm{~mL}$ of $1: 1: 1$ acetone/ethanol/water solution and the amount of fatty acids was quantified through titration reaction with $0.05 \mathrm{M} \mathrm{NaOH}$ in a titrator (Metrohm Titrino 794, Herisau, Switzerland) until pH end-point was equal to 11. Blank assays were conducted by adding the enzyme just before titration. One unit $(U)$ of lipase activity was defined as the amount of enzyme, which produces $1 \mu \mathrm{mol}$ of fatty acids per minute under assay conditions. All analyses were carried out in duplicate. The specific activity of the enzyme extract was calculated by the ratio between lipase activity and protein content.

\section{Protease Activity}

Protease activity was determined based on colorimetric method using azocasein described by Charney and Tomarelli [20]. One unit of protease activity was defined as the amount of enzyme that produces a unitary change in absorbance $(428 \mathrm{~nm})$ per minute under assay conditions.

\section{Determination of protein}

Protein was estimated by the Folin-Ciocalteau's phenol reagent as outlined by Lowry et al [21], at $660 \mathrm{~nm}$, using bovine serum albumin (BSA) as standard.

\section{Determination of reducing sugars}

The concentrations of total reducing sugars (TRS) were quantified by the 3,5-dinitrosalicylic acid (DNS) method [22].

\section{Biomass estimation}

Biomass was estimated according to Singh et al[23] with modification. The culture broth was filtered through pre-weighed Whatman No.1 filter paper. The filter paper containing the biomass was dried at $65^{\circ} \mathrm{C}$ for $24 \mathrm{~h}$ and its dry weight was estimated.

\section{Effect of $\mathrm{pH}$ and temperature on enzyme activity}

The effect of $\mathrm{pH}$ and temperature was performed by the lipase activity determination, as previously described. The $\mathrm{pH}$ effects were measured using buffers of different $\mathrm{pH}$ 's (5 - 8) at $35^{\circ} \mathrm{C}$. The employed buffers were as follows: $0.1 \mathrm{M}$ citrate buffer $(\mathrm{pH} 3-6) ; 0.1 \mathrm{M}$ Na-phosphate buffer ( $\mathrm{pH} 6$ - 8). Temperature influence was evaluated by carrying out the enzyme assay at 25 to $55^{\circ} \mathrm{C}$ temperatures range, using $0.1 \mathrm{M}$ citrate buffer $\mathrm{pH} 5$.

\section{RESULTS AND DISCUSSION}

\section{Experimental Design}

The first step in the optimization strategy was to identify medium components with significant effects on the production of lipases by SmF. A fractional factorial design $2^{5-1}$ was used to evaluate five independent variables: $\mathrm{pH}$ and the sucrose, soybean oil, yeast extract and ammonium sulphate concentrations, from 16 runs and three replicates at the central point, as shown in Table 3. The dependent variable was the enzymatic activity (U. $\left.\mathrm{mL}^{-1}\right)$.

The highest lipase activity $\left(13.12 \mathrm{U} \cdot \mathrm{mL}^{-1}\right)$ was found at the central point $\left(15.0 \mathrm{~g} . \mathrm{L}^{-1}\right.$ sucrose, $4.0 \mathrm{~g} . \mathrm{L}^{-1}$ ammonium sulphate, $4.0 \mathrm{~g} . \mathrm{L}^{-1}$ of soybean oil, $1.0 \mathrm{~g} . \mathrm{L}^{-1}$ yeast extract and $\mathrm{pH}$ 7.0) while experiments performed in the test 3 presented no activity in 72 hours.

The data in Table 3 show that the final $\mathrm{pH}$ of enzyme extract was low, regardless of initial $\mathrm{pH}$. Therefore, immediately after enzyme extract recovery, a correction of $\mathrm{pH}$ was conducted to reach $\mathrm{pH} 5.0$, in order to keep enzyme activity. 
An explanation for $\mathrm{pH}$ reduction at the end of fermentation may be related to the effect of hydrolysis of triglycerides, which are added to the fermentation medium as enzyme synthesis inducers. The selected inducer was soybean oil, which has high linoleic and linolenic acids contents in its composition, polyunsaturated fatty and reactive acids. Polyunsaturated fatty acids are easily hydrolyzed and fatty acids release reduces the medium $\mathrm{pH}$. In addition, $\mathrm{pH}$ reduction may be associated with organic acids production by $A$. niger [24].

Table 3. Matrix and results of the FFD $2^{5-1}$ for the production of lipase with their coded and real levels

\begin{tabular}{|c|c|c|c|c|c|c|c|}
\hline Assays & $\begin{array}{c}\text { Sucrose } \\
\left(g \cdot L^{-1}\right)\end{array}$ & $\begin{array}{c}\left(\mathrm{NH}_{4}\right)_{2} \mathrm{SO}_{4} \\
\left(\mathrm{~g} \cdot \mathrm{L}^{-1}\right)\end{array}$ & $\begin{array}{c}\text { SO } \\
\left(g \cdot L^{-1}\right)\end{array}$ & $\begin{array}{c}\text { YE } \\
\left(g \cdot L^{-1}\right)\end{array}$ & $\mathrm{pH}_{\text {initial }}$ & $\begin{array}{c}\text { EA } \\
\left(\text { U.mL } L^{-1}\right) \\
\end{array}$ & $\mathrm{pH}_{\text {final }}$ \\
\hline 1 & $-1(10)$ & $-1(2)$ & $-1(2)$ & $-1(0)$ & $1(8)$ & 1.24 & 2.7 \\
\hline 2 & $1(20)$ & $-1(2)$ & $-1(2)$ & $-1(0)$ & $-1(6)$ & 0.97 & 1.9 \\
\hline 3 & $-1(10)$ & $1(6)$ & $-1(2)$ & $-1(0)$ & $-1(6)$ & 0.00 & 2.2 \\
\hline 4 & $1(20)$ & $1(6)$ & $-1(2)$ & $-1(0)$ & $1(8)$ & 1.60 & 1.9 \\
\hline 5 & $-1(10)$ & $-1(2)$ & $1(6)$ & $-1(0)$ & $-1(6)$ & 2.72 & 1.9 \\
\hline 6 & $1(20)$ & $-1(2)$ & $1(6)$ & $-1(0)$ & $1(8)$ & 2.67 & 2.3 \\
\hline 7 & $-1(10)$ & $1(6)$ & $1(6)$ & $-1(0)$ & $1(8)$ & 0.88 & 2.7 \\
\hline 8 & $1(20)$ & $1(6)$ & $1(6)$ & $-1(0)$ & $-1(6)$ & 3.76 & 1.8 \\
\hline 9 & $-1(10)$ & $-1(2)$ & $-1(2)$ & $1(2)$ & $-1(6)$ & 1.51 & 3.6 \\
\hline 10 & $1(20)$ & $-1(2)$ & $-1(2)$ & $1(2)$ & $1(8)$ & 0.22 & 3.2 \\
\hline 11 & $-1(10)$ & $1(6)$ & $-1(2)$ & $1(2)$ & $1(8)$ & 0.44 & 3.6 \\
\hline 12 & $1(20)$ & $1(6)$ & $-1(2)$ & $1(2)$ & $-1(6)$ & 0.39 & 2.2 \\
\hline 13 & $-1(10)$ & $-1(2)$ & $1(6)$ & $1(2)$ & $1(8)$ & 0.30 & 5.7 \\
\hline 14 & $1(20)$ & $-1(2)$ & $1(6)$ & $1(2)$ & $-1(6)$ & 5.43 & 2.1 \\
\hline 15 & $-1(10)$ & $1(6)$ & $1(6)$ & $1(2)$ & $-1(6)$ & 3.53 & 3.6 \\
\hline 16 & $1(20)$ & $1(6)$ & $1(6)$ & $1(2)$ & $1(8)$ & 1.51 & 2.5 \\
\hline $17^{\star}$ & $0(15)$ & $0(4)$ & $0(4)$ & $0(1)$ & $0(7)$ & 13.01 & 2.3 \\
\hline $18^{*}$ & $0(15)$ & $0(4)$ & $0(4)$ & $0(1)$ & $0(7)$ & 12.48 & 2.0 \\
\hline $19^{*}$ & $0(15)$ & $0(4)$ & $0(4)$ & $0(1)$ & $0(7)$ & 13.87 & 2.2 \\
\hline
\end{tabular}

${ }^{*}$ Central points / Absolute values between parenthesis / SO = Soybean oil; YE = Yeast extract; EA = Enzymatic activity

The fractional factorial design $2^{5-1}$ used in the first step of this study indicated that the lipase production by $A$. niger $\mathrm{C}$ in $\mathrm{SmF}$, under the conditions tested, was influenced by the concentration of inducer and the initial $\mathrm{pH}$ of the medium at $90 \%$ confidence level. The Pareto chart (Figure 1) shows a tendency that the lipase production by $A$. niger $\mathrm{C}$ can be improved by increasing the inducer concentration and decreasing the $\mathrm{pH}$ of the fermentation medium, although the highest activity was obtained at the central point. On the other hand, sucrose, ammonium sulphate and yeast extract did not significantly influence lipase activity in the range studied. The interaction of soybean oil and $\mathrm{pH}$ presented negative effects on lipase activity. The others interaction between independent variables did not show a significant effect (data not shown). Figure 1 also depicts that curvature was statistically significant, so the model is not linear and stars points was added in the next experimental design in order to evaluate if the quadratic model to fit the experimental data.

In this work, lipase production was influenced by soybean oil concentration. Lipase production is rarely constitutive and the quantity of the extracellular lipase produced is scarce. Hence inductors like vegetables oils are frequently used. When oil is used as carbon 
source, the microorganism uses sequentially the glycerol and fatty acids components of the oil. First, the oil is hydrolyzed and, then, the microorganism consumes glycerol without lipase production. Finally, the free fatty acids are consumed simultaneously with the formation of a significant amount of lipases. It is suggested that long-chain fatty acids participate in the expression of the fungal lipase genes [25].

The initial $\mathrm{pH}$ also proved to be an important variable for the production of lipases, with the optimal value being approximately 7.0. This result is in agreement with Sethi et al [16] who studied $\mathrm{pH} \mathrm{3-10} \mathrm{in} \mathrm{the} \mathrm{production} \mathrm{of} \mathrm{lipase} \mathrm{by} A$. terreus, where the best result was obtained with pH 6.0. Muralidhar et al [26] used an initial pH of 6.5 in the culture of Candida cylindracea. Teng and $\mathrm{Xu}$ [27] studied the effect of $\mathrm{pH}$ on the production of lipases by Rhyzopus chinensis between $\mathrm{pH}$ values 5 and 7 , and the best results were achieved at $\mathrm{pH}$ 5.5. Each microorganism has a $\mathrm{pH}$ for optimal growth. In this case, $\mathrm{pH}$ could have affected lipase synthesis beyond microorganism growth.

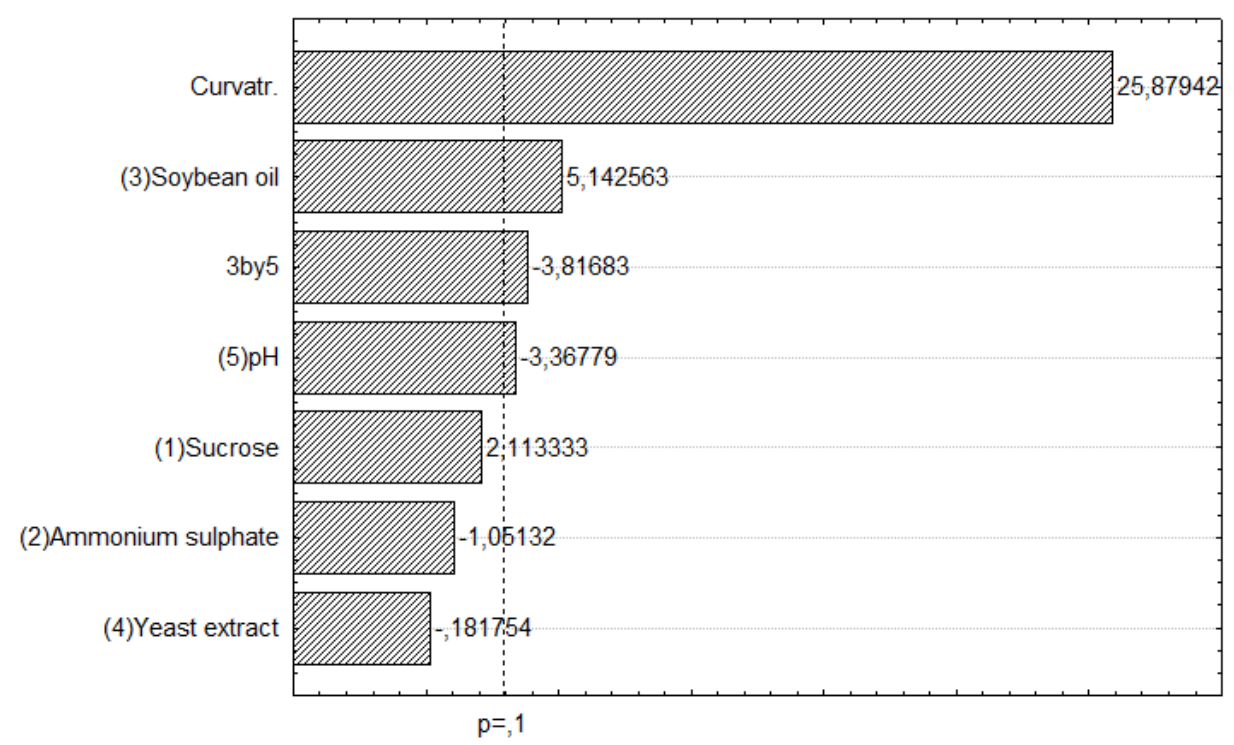

Figure 1. Pareto Chart of standardized effects for lipase production by $A$. niger $C$ for the FFD $2^{5-1}$. The point at which the effects estimates were statistically significant $(p \leq 0.1)$ is indicated by the broken vertical line.

In order to evaluate the influence of the interaction between $\mathrm{pH}$ and soybean oil (inducer) a second experimental design was carried out with a central composite rotatable design (CCRD) $2^{2}$. The concentration ranges of variables, indicated in Table 2 , were selected according to the previous responses for the FFD $2^{5-1}$.

The results for the CCRD $2^{2}$ are present in Table 4. Data indicates that enzymatic activity vary markedly from 1.56 a $30.76 \mathrm{U} \mathrm{m} . \mathrm{L}^{-1}$. 
Table 4. Matrix and results of the CCRD $2^{2}$ for the production of lipase with their coded and real levels

\begin{tabular}{ccccccc}
\hline Assays & $\begin{array}{c}\mathbf{S O} \\
\left(\mathbf{g} \cdot \mathbf{m L}^{-1}\right)\end{array}$ & $\mathbf{p H}_{\text {initial }}$ & $\mathbf{p H}_{\text {final }}$ & $\begin{array}{c}\mathbf{E A} \\
\left(\mathbf{U} \cdot \mathbf{m L}^{-1}\right)\end{array}$ & $\begin{array}{c}\mathbf{R S} \\
\left(\mathbf{g} \cdot \mathbf{L}^{-1}\right)\end{array}$ & $\begin{array}{c}\text { Cell } \\
\text { Biomass } \\
\left(\mathbf{g} . \mathbf{L}^{-1} \mathbf{)}\right.\end{array}$ \\
\hline 1 & $-1(4)$ & $-1(5)$ & 2.4 & 27.46 & 0.24 & 9.5 \\
2 & $+1(8)$ & $-1(5)$ & 2.8 & 30.76 & 0.28 & 11.1 \\
3 & $-1(4)$ & $+1(7)$ & 3.2 & 19.8 & 0.26 & 10.4 \\
4 & $+1(8)$ & $+1(7)$ & 2.3 & 4.29 & 0.29 & 10.2 \\
5 & $-1.41(3.18)$ & $0(6)$ & 2.1 & 1.56 & 0.35 & 11.6 \\
6 & $+1.41(8.82)$ & $0(6)$ & 2.1 & 2.79 & 0.40 & 10.4 \\
7 & $0(6)$ & $-1.41(4.59)$ & 1.9 & 14.20 & 0 & 13.2 \\
8 & $0(6)$ & $+1.41(7.41)$ & 2.7 & 2.66 & 0 & 14.6 \\
$9^{*}$ & $0(6)$ & $0(6)$ & 2.2 & 15.71 & 0 & 14.2 \\
$10^{*}$ & $0(6)$ & $0(6)$ & 2.2 & 13.13 & 0 & 13.7 \\
$11^{*}$ & $0(6)$ & $0(6)$ & 2.2 & 14.57 & 0 & 14.7 \\
\hline
\end{tabular}

${ }^{*}$ Central points / Absolute values between parenthesis / SO = Soybean oil; EA = Enzymatic activity;

$$
\mathrm{RS}=\text { Reducing sugars }
$$

High lipase production (27.46 and $30.76 \mathrm{U} . \mathrm{mL}^{-1}$ ) was found at experiments number 1 and 2 when $\mathrm{pH}$ was 5.0. The enzymatic activity $\left(30.76 \mathrm{U} . \mathrm{mL}^{-1}\right)$ was 2.3 fold higher than the initial lipase production process $\left(13.12 \mathrm{U} \cdot \mathrm{mL}^{-1}\right)$.

In the runs 7 to 11 (Table 4), a mean dry biomass increase of until $33 \%$ was observed in relation to the other runs, which may be related to the medium total sucrose consumption. Sucrose consumption in these runs seems to be related to both biomass and lipase production, except in experiment $8(\mathrm{pH}>7)$, in which activity was low.

Figure 2 illustrates the Pareto chart, with $90 \%$ of confidence level, for the estimated effects in absolute values for lipase production. It is possible to observe that $\mathrm{pH}$ (linear term), soybean oil (quadratic term), $\mathrm{pH}$-soybean oil interaction (1L by $2 \mathrm{~L}$ ) had significantly influenced the dependent variable. Figure 2 also depicts that the decrease in $\mathrm{pH}$ and soybean oil concentration showed positive effects on lipase production in the range studied.

The variance analysis was performed and shows that the model is not significant, as is evident from the Fisher $F$ test, where the calculated $F$ values $(F=1.55)$ are lower than the tabular $F$ value $(F=4.35)$. The values for the determined coefficients were 0.42 for enzymatic activity. The model does not fit the data well, probably because there is some other important variable for the model that has not been evaluated. In this case, the objective of the study was reached, showing that the chosen conditions influence on lipase production. Moreover, there was an increase in production by the modification of the culture conditions, as seen by the results of FFD and CCRD.

It was observed that $A$. niger $C$ lipase activity $\left(30.76\right.$ U. $\left.\mathrm{mL}^{-1}\right)$ obtained in this study were higher and/or similar to results reported in the literature: $4.52 \mathrm{U} \cdot \mathrm{mL}^{-1}$ and $25.07 \mathrm{U} \cdot \mathrm{mL}^{-1}$ [28] and 40.1 U. $\mathrm{mL}^{-1}$ [29], both employing the fungus Aspergillus sp. Using Trichoderma harzianum, Coradi et al [14] obtain 1.4 U. $\mathrm{mL}^{-1}$ while Kishan et al [8] found $9.40 \mathrm{U} \cdot \mathrm{mL}^{-1}$ with Yarrowia lipolytica. These results indicate that the $A$. niger $\mathrm{C}$ strain produced the lipase enzyme at satisfactory levels when compared to levels already reported in the literature.

All subsequent experiments were conducted under assay conditions $1\left(4 \mathrm{~g} . \mathrm{L}^{-1}\right.$ soybean oil and $\mathrm{pH} 5.0)$, selected in CCRD $2^{2}$. Although the highest lipase activity $\left(30.76 \mathrm{U} \cdot \mathrm{mL}^{-1}\right)$ was that of assay $2\left(8 \mathrm{~g} \cdot \mathrm{L}^{-1}\right.$ soybean oil and $\left.\mathrm{pH} 5.0\right)$, the assay condition 1 was chosen, since lipase activity (27.46 U. $\mathrm{mL}^{-1}$ ) was very close to that of assay 2 , even though using half of the inducer concentration, consequently reducing process cost. 


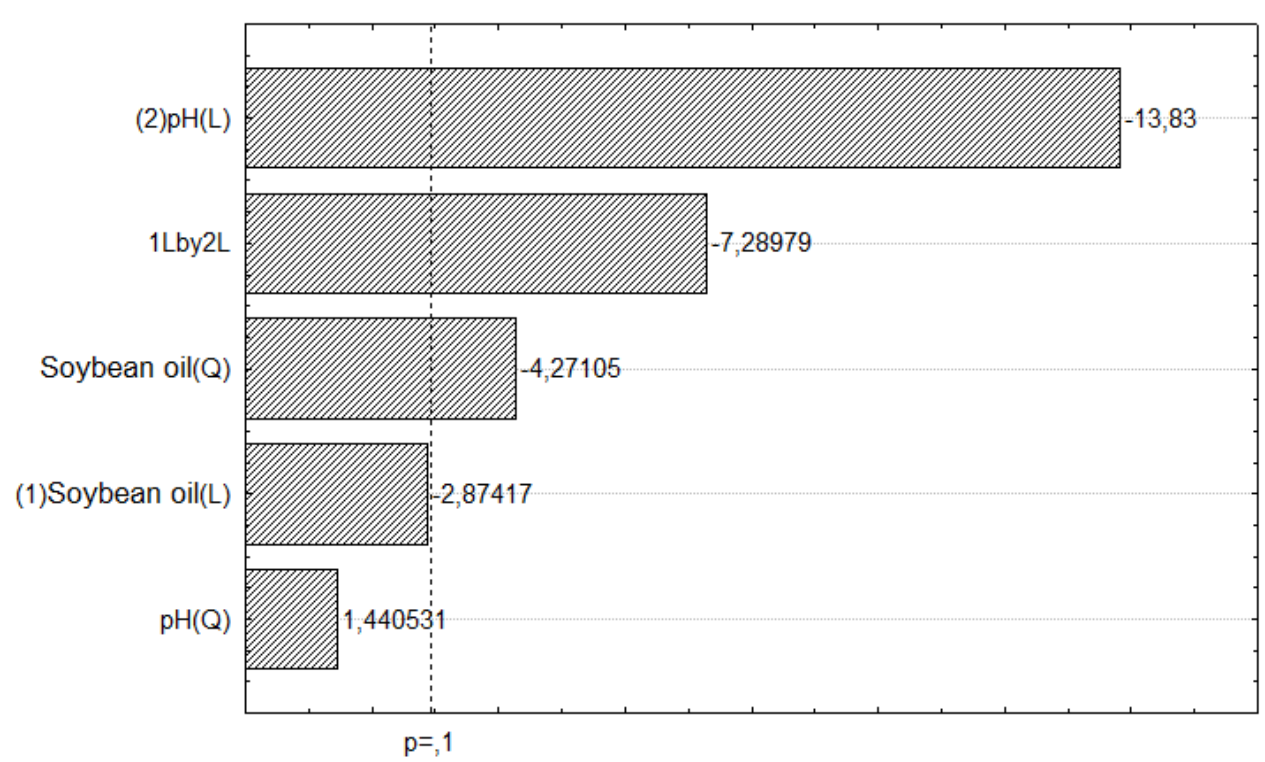

Figure 2. Pareto Chart of standardized effects for enzymatic activity of CCRD 22 used in the optimization of lipase production. The point at which the effects estimates were statistically significant $(p=0.1)$ is indicated by the broken vertical line. $L$ - Linear term and $Q$ - Quadratic term.

\section{Kinetics of lipase production}

Figure 3 shows the results of analysis of the dry biomass, total reducing sugars concentration and specific activity. Protease activity was not observed.

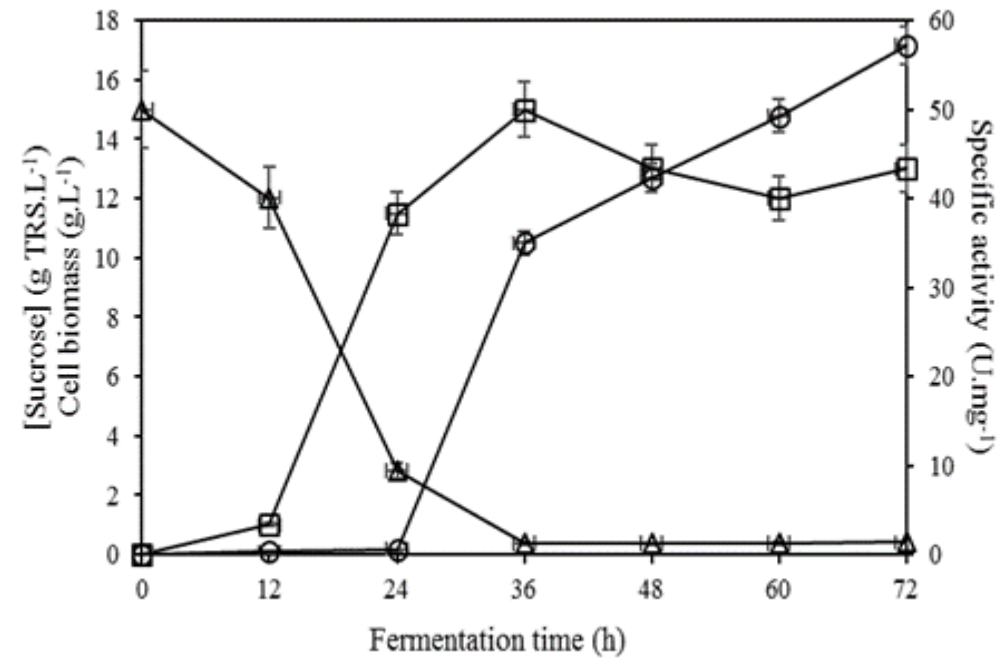

Figure 3. Kinetics profile of lipase production by A. niger C by FS. Assay conditions: $4 \mathrm{~g}$. L-1 soybean oil and $\mathrm{pH}$ 5.0. ( $\Delta$ ) [Sucrose], (ם) Cell biomass, (o) Specific activity. The bar represents the percentage error (TRS - total reducing sugars).

It can be verified that the growth of the fungi reached a maximum around 36 hours $(15.2$ $\mathrm{g} \cdot \mathrm{L}^{-1}$ ), being the sucrose almost totally consumed (final concentration equal to $0.35 \mathrm{~g} \cdot \mathrm{L}^{-1}$ ). However, at 48 hours, there was a small decrease in the dry biomass concentration (13.0 g. $\mathrm{L}^{-1}$ ) (Figure 3 ). This profile suggests that with the exhaustion of the main carbon source, some microbial cells may have undergone autolysis with release of intracellular lipase, increasing its concentration in the enzymatic extract.

The highest specific activity (57.17 U. $\left.\mathrm{mg}^{-1}\right)$ was obtained at 72 hours. It is related to the low protein concentration $\left(0,23 \mathrm{~g} \cdot \mathrm{L}^{-1}\right)$ in the enzymatic extract. Silva et al [30] investigated the production of lipase by Metarhizium anisopliae with different lipid sources, obtaining with 
soybean oil, the same lipid source used in this study, a similar specific activity (56.47 U.mg ${ }^{-1}$ ).

\section{Effect of $\mathrm{pH}$ and temperature}

The $\mathrm{pH}$ effect on the lipase activity produced in this study was investigated between $\mathrm{pH}$ 5.0 and 8.0. The results are shown in Figure 4.

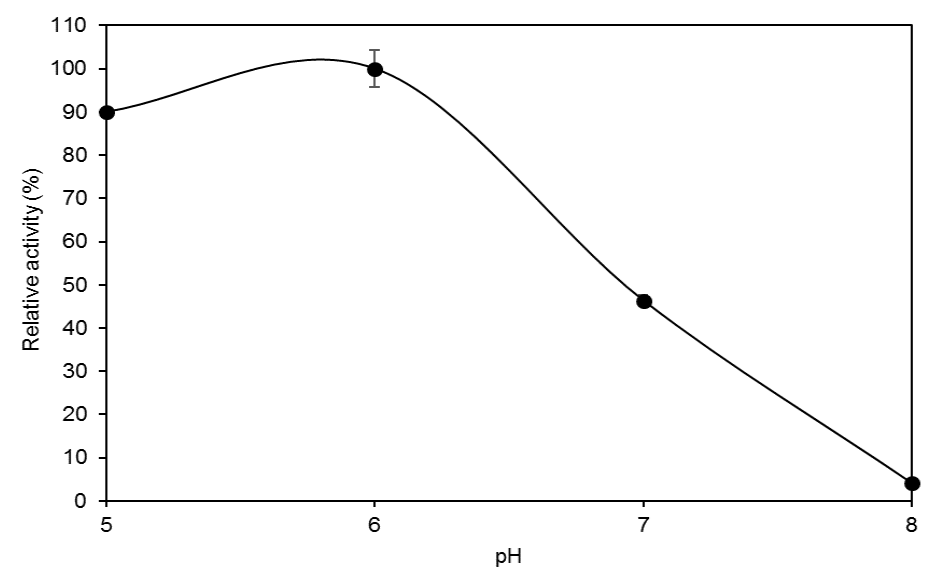

Figure 4. Effect of $\mathrm{pH}$ on lipase activity

The enzyme extract showed activity in all $\mathrm{pH}$ values analyzed. At $\mathrm{pH} 8.0$, the enzyme showed only $4 \%$ of relative activity, and at $\mathrm{pH} 7.0$, there was relative activity loss of around $50 \%$. The results indicated that the best $\mathrm{pH}$ range of lipase produced by $A$. niger $\mathrm{C}$ was between 5.0 and 6.0. The result afore mentioned can be explained by the ionization state of an enzyme, which varies according to $\mathrm{pH}$ and may affect the enzymatic reaction rate. The conformation and/or flexibility of the enzyme and its active site are established by ionic interactions. Thus, the ionization state of side groups is modified under different $\mathrm{pH}$ conditions, which may interrupt these forces and alter and/or denature the protein structure $[31,32]$. Consequently, all enzymes have a pH which act with maximum potential, called optimal $\mathrm{pH}$, in which they reach high activity levels.

Temperature effect on lipase activity was investigated between 25 and $55^{\circ} \mathrm{C}$, and results are shown in Figure 5.

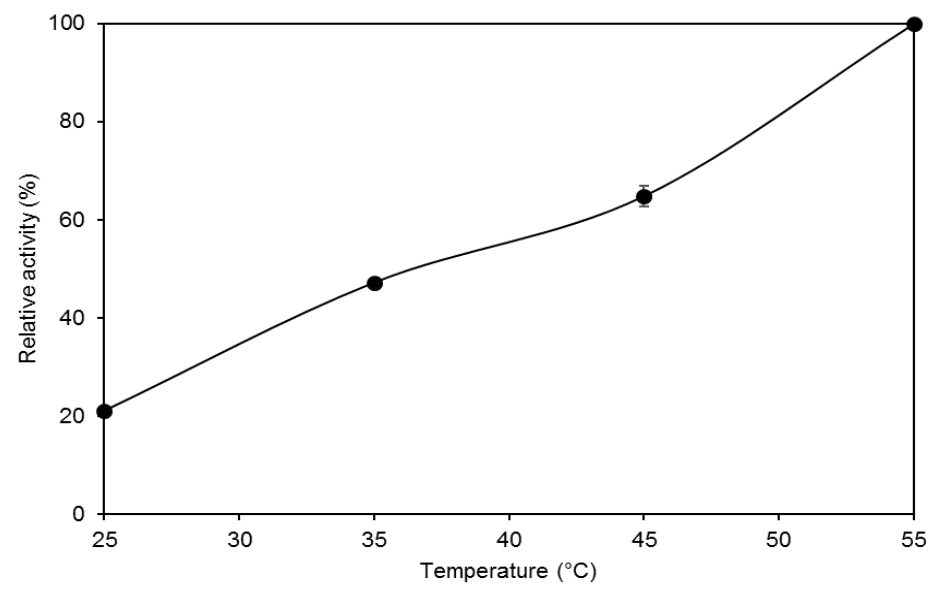

Figure 5. Effect of temperature on lipase activity

The enzymatic extract showed activity in all temperatures evaluated. The lowest activity was at $\mathrm{T}=25^{\circ} \mathrm{C}(21 \%$ of relative activity). It was observed that activity increased along with temperature, where the most adequate temperature was $55^{\circ} \mathrm{C}$. Denaturation temperature 
was not reached in the range studied. Usually, increasing the temperature increases reactant molecules kinetic energy, increasing the amount of effective shocks between them and reaction speed. This effect is observed in a specific temperature range in which the enzyme three-dimensional shape is conserved. However, higher temperatures cause enzyme denaturation, as they cause enzyme native structure loss, since the chemical bonds that hold enzyme spatial structures are altered. Denaturation temperature varies according to the enzyme, but it is generally slightly above its optimum temperature, which, in turn, is very similar to its natural environment temperature $[33,5]$.

Some papers in the literature demonstrate that lipase activity ranges in relation to $\mathrm{pH}$ and temperature may vary according to microorganism [34, 35].

Pera et al [36] studied the biocatalytic properties and stability of lipase extracts produced by Aspergillus niger MYA 135, they found optimum $\mathrm{pH}$ and temperature around 6.0 and $35^{\circ} \mathrm{C}$, respectively. Differently, in the study by Colla et al [37], the maximum activity of a lipase produced by $A$. flavus was obtained at $\mathrm{pH} 7.2$ and $37^{\circ} \mathrm{C}$.

Pastore et al [38] determined $40^{\circ} \mathrm{C}$ and $\mathrm{pH}$ between 6.0 and 6.5 as the optimal temperature and $\mathrm{pH}$ in their study on Rhizopus sp. lipase characterization. Pinheiro [39], while studying Penicillium verrucosum lipase characterization, determined $44^{\circ} \mathrm{C}$ as optimal temperature and 7.0 as optimum $\mathrm{pH}$.

Given the above, it is observed that $A$. niger $C$ lipase production by submerged fermentation in shaken flasks has promising results, allowing the continuity of this study at pilot-scale with some pre-selected variables.

\section{CONCLUSIONS}

Experiment design was an efficient tool in improving $A$. niger $\mathrm{C}$ lipase production. The use of experimental design techniques allowed a greater understanding of the effect of the independent variables on lipase production. This tool showed that, between $\mathrm{pH} 4.0$ and 6.0, the highest activities were recorded in the soybean oil concentration above $4 \mathrm{~g} . \mathrm{L}^{-1}$. When the $\mathrm{pH}$ was higher than 6.0 , the best enzymatic activity was found in low soybean oil concentration regions, i.e., less than $4 \mathrm{~g} . \mathrm{L}^{-1}$. The assay condition selected $\left(15.0 \mathrm{~g} . \mathrm{L}^{-1}\right.$ sucrose, $4.0 \mathrm{~g} . \mathrm{L}^{-1}$ ammonium sulphate, $4.0 \mathrm{~g} \cdot \mathrm{L}^{-1}$ soybean oil and $1.0 \mathrm{~g} \cdot \mathrm{L}^{-1}$ yeast extract and $\mathrm{pH} 5.0$ ) was the one that presented a lipase activity of $27.46 \mathrm{U} \cdot \mathrm{mL}^{-1}$.

Lipase production kinetics indicated that it is possible to achieve good yield levels in a short fermentation time, which is very important in industrial processes, since time and energy saving are fundamental conditions in large-scale production.

Biochemical characterization regarding enzyme extract $\mathrm{pH}$ and temperature indicated that the lipase produced by $A$. niger $\mathrm{C}$ has optimum activity in a more acidic $\mathrm{pH}$ (5.0-6.0) and tendency to thermostability, since the best reaction temperature was $55^{\circ} \mathrm{C}$ in the range studied.

\section{REFERENCES}

1. Campbell MK, Farrell SO. Bioquímica: Bioquímica básica. 4th ed. São Paulo: Thomson Learning; 2007.

2. Joseph B, Ramteke PW, Thomas G. Cold active microbial lipases: some hot issues and recent developments. Biotechnol Adv. 2008;26:457-70.

3. Singh R, Kumar M, Mittal A, Mehta PK. Microbial enzymes: industrial progress in 21st century. Biotech. 2016;6:1-15.

4. Guerrand D. Lipases industrial applications: focus on food and agroindustries. OCL. 2017;24:D403.

5. BCC Research Biotechnology. Global markets for enzymes in industrial applications. [Internet]. [place unknown]: BCC Publishing; 2017 Jan [cited 2018 Feb 5]. Available from: 
https://www.bccresearch.com/market-research/biotechnology/enzymes-industrial-applications-r eport-bio030j.html

6. Fernandez-Lafuente R. Lipase from Thermomyces lanuginosus: uses and prospects as an industrial biocatalyst. J Mol Catal B: Enzym. 2010;62:197-212.

7. Show P-L, Ling T-C, Lan JC-W, Tey B-T, Ramanan RN, Yong S-T, et al. Review of microbial lipase purification using aqueous two-phase systems. Curr Org Chem. 2015;19:19-29.

8. Kishan G, Gopalakannan P, Muthukumaran C, Muthukumaresan KT, Kumar MD, Tamilarasan K. Statistical optimization of critical medium components for lipase production from Yarrowia lipolytica (MTCC 35). J Gen Eng Biotechnol. 2013;11:111-6.

9. Salihu A, Bala M, Bala SM. Application of plackett-burman experimental design for lipase production by Aspergillus niger using Shea Butter Cake. ISRN Biotechnol. 2013;2013: Article ID 718352, 5 pages. doi:10.5402/2013/718352.

10. Messias JM, Costa BZ, Lima VMG, Dekker RFH, Rezende MI, Krieger N, et al. Screening Botryosphaeria species for lipases: Production of lipase by Botryosphaeria ribis EC-01 grown on soybean oil and other carbon sources. Enzyme Microb Technol. 2009;45:426-31.

11. Santos RR, Muruci LNM, Damaso MCT, Silva JPL, Santos LO. Lipase production by Aspergillus niger 11T53A14 in wheat bran using experimental design methodology. J Food Nutr Res. 2014;2:659-66.

12. Renge VC, Khedkar SV. Enzyme synthesis by fermentation method: a review. Sci Revs Chem Commun. 2012;4:585-90.

13. Singhania RR, Sukumaran RK, Patel AK, Larroche C, Pandey A. Advancement and comparative profiles in the production technologies using solid-state and submerged fermentation for microbial cellulases. Enzyme Microb Tech. 2010;46:541-9.

14. Coradi GV, Da Visitação VL, De Lima EA, Saito LYT, Palmieri DA, Takita MA, De Lima VMG. Comparing submerged and solid-state fermentation of agro-industrial residues for the production and characterization of lipase by Trichoderma harzianum. Ann Microbiol. 2013;63:533-40.

15. Nwuche CO, Ogbonna JC. Isolation of lipase producing fungi from palm oil mill effluent (POME) dump sites at Nsukka. Braz Arch Biol Techn. 2011;54:113-6.

16. Sethi BK, Rout JR, Nanda PK, Sahoo SL. Lipase production by Aspergillus terreus using mustard seed oil cake as a carbon source. Ann Microbiol. 2013;63:241-52.

17. Salihu A, Bala M, Alam MZ. Lipase production by Aspergillus niger using sheanut cake: An optimization study. J Taibah Uni Sci. 2016;10:850-9.

18. Couri S, Farias AX. Genetic manipulation of Aspergillus niger for increased synthesis of pectinolytic enzymes. Rev Microbiol. 1995;26:314-7.

19. Damaso MCT, Passianoto MA, Freitas SCD, Freire DMG, Lago RCA, Couri S. Utilization of agroindustrial residues for lipase production by solid-state fermentation. Braz J Microbiol. 2008;39:676-81.

20. Charney J, Tomarelli RM. A colorimetric method for the determination of the proteolytic activity of duodenal juice. J Biol Inorg Chem. 1947;171:501-5.

21. Lowry OH, Rosebrough NJ, Farr AL, Randall RJ. Protein measurement with the Folin phenol reagent. J Biol Chem. 1951;193:265-75.

22. Miller GL. Use oi Dinitrosalicylic Acid Reagent tor determination oi reducing sugar. Anal Chem. 1959;31:426-28. 
23. Singh K, Nizam S, Sinha M, Verma PK. Comparative transcriptome analysis of the necrotrophic fungus Ascochyta rabiei during oxidative stress: insight for fungal survival in the host plant. PLoS ONE. 2012;7(3): e33128. doi:10.1371/journal.pone.0033128.

24. Muruci LNM, Santos RR, Couri S, Penha EM, Damaso MCT. Estudo das características físico-químicas de lipase de Asgergillus niger visando sua aplicação em alimentos. Hig. Alimentar. 2013;27:1-5.

25. Montesinos JL, Obradors N, Gordillo MA, Valero F, Lafuente J, Sola C. Effect of nitrogen sources in batch and continuous cultures to lipase production by Candida rugosa. Appl Biochem Biotechnol. 1996;59:25-37.

26. Muralidhar RV, Chirumamila RR, Marchant R, Nigam P. A response surface approach for the comparison of lipase production by Candida cylindracea using two different carbon sources. Biochem Eng J. 2001;9:17-23.

27. Teng $\mathrm{Y}, \mathrm{Xu} \mathrm{Y}$. Culture condition improvement for whole-cell lipase production in submerged fermentation by Rhizopus chinensis using statistical method. Bioresource Technol. 2008;99:3900-07.

28. Colla LM, Rizzardi J, Pinto MH, Reinehr CO, Bertolin TE, Costa JAV. Simultaneous production of lipases and biosurfactants by submerged and solid-state bioprocesses. Bioresource Technol. 2010;101:8308-14.

29. Mahadik ND, Bastawde KB, Puntambekar US, Khire JM, Gokhale DV. Production of acidic lipase by a mutant of Aspergillus niger NCIM 1207 in submerged fermentation. Process Biochem. 2004;39:2031-4.

30. Silva WOB, Mitidieri S, Schrank A, Vainstein MH. Production and extraction of an extracellular lipase from the entomopathogenic fungus Metarhizium anisopliae. Process Biochem. 2005;40:321-6.

31. Adlercreutz P. Immobilisation and application of lipases in organic media. Chem Society Revs. 2013;42:6406-36.

32. Xu T-W, Xu J-H, Yu W, Zhong J-H. Investigating $\mathrm{pH}$ and $\mathrm{Cu}$ (II) effects on lipase activity and enantioselectivity via kinetic and spectroscopic methods. Biotechnol J. 2006;1:1293-301.

33. Borzani W, Aquarone E, Lima UA, Schmidell W. Biotecnologia industrial: Fundamentos. 2th ed.; São Paulo: Blocher; 2001.

34. Qi W, Wang H, Liu R, Gao C, Lu F. High-level production and characterisation of the recombinant thermostable lipase of Geobacillus thermoleovorans in Pichia methanolica. Ann Microbiol. 2008;58:121-5.

35. Lopes VRO, Farias MA, Belo IMP, Coelho MAZ. Nitrogen sources on TPOMW valorization through solid state fermentation performed by Yarrowia lipolytica. Braz J Chem Eng. 2016;33:261-70.

36. Pera LM, Romero CM, Baigori MD, Castro GR. Catalytic properties of lipase extracts from Aspergillus niger. Food Technol Biotech. 2006;44:247-52.

37. Colla LM, Ficanha AM, Rizzardi J, Bertolin TE, Reinehr CO, Costa JAV. Production and characterization of lipases by two new isolates of Aspergillus through solid-state and submerged fermentation. BioMed Res Int. 2015;2015:1-9.

38. Pastore GM, Costa VSR, Koblitz MGB. Purificação parcial e caracterização bioquímica de lipase. Ciência e Tecnologia de Alimentos. 2003;23:135-40. 
39. Pinheiro TLF. Produção de lipases por fermentação em estado sólido e fermentação submersa utilizando Penicillium verrucosum como microrganismo [master's thesis]. Erechim (RS, BR): Universidade Regional Integrada do Alto Uruguai e das Missões; 2006.

(ब) $(1)(8$

2018 by the authors. Submitted for possible open access publication under the terms and conditions of the Creative Commons Attribution (CC BY NC) license (https://creativecommons.org/licenses/by-nc/4.0/). 